\title{
PENGARUH PENERAPAN TEKNOLOGI INFORMASI TERHADAP KINERJA KARYAWAN DI KOPERASI PONDOK PESANTREN MAMBAUL KHOIRIYATIL ISLAMIYAH (MHI) JEMBER
}

\author{
Akhmad Yunan Athoillah \\ Dosen FEBI UINSA Surabaya | \\ yunanathoillah@gmail.com
}

\begin{abstract}
Abstrak: Penelitian ini bertujuan untuk menguji pengaruh penerapan teknologi informasi terhadap kinerja karyawan dengan kemampuan pengguna sebagai variabel moderasi pada Koperasi Pondok Pesantren Mambaul Khoiriyatil Islamiyah (MHI) Jember.

Pengumpulan data dalam penelitian ini dilakukan dengan penyebaran kuisoner kepada populasiyang secara menyeluruh dijadikan sampel yakni seluruh karyawan yang bekerja di kantor pusat. Analisis data dengan menggunakan uji regresi linier sederhana untuk hipotesis pertama dan hipotesis kedua dengan metode MRA (Moderated Regression Analysis).

Hasil penelitian menunjukkan bahwa penerapan teknologi informasi berpengaruh positif dan signifikan terhadap kinerja karyawan, sedangkan untuk variabel moderasi dari hasil uji hipotesis kedua menunjukkan hasil bahwa variabel kemampuan pengguna berpengaruh positif dan tidak signifikan terhadap hubungan antara penerapan teknologi informasi dengan kinerja karyawan, tetapi variabel kemampuan pengguna memperlemah interaksi antara variabel penerapan teknologi informasi terhadap kinerja karyawan. Jadi dapat dikatakan kemampuan pengguna sebagai variabel moderasi potensial (Homologiser).
\end{abstract}

Keywords : Penerapan Teknologi Informasi, Kemampuan Pengguna, Kinerja Karyawan, Kopotren $\mathrm{MHI}$ Jember 


\section{Pendahuluan}

Teknologi informasi adalah salah satu dari jenis teknologi yang berbentuk peralatan teknis dan berfungsi untuk memproses dan menyampaikan informasi. Teknologi informasi termasuk serangkaian peralatan yang berfungsi sebagai alat untuk memproses data atau informasi, alat bantu, alat manipulasi, dan alat pengelolaan informasi. ${ }^{1}$ Teknologi digital kini merupakan bagian yang integral dari sumber daya perusahaan dan manajer menggunakannya dalam pengelolaan bisnis sehari-hari. Setiap aktivitas bisnis penting perusahaanseperti perancangan layanan, pemantauan pengiriman produk dan arus kas, evaluasi karyawan, serta pembuatan iklan-terkait dengan sistem informasi. ${ }^{2}$ Teknologi informasi berfungsi untuk memperoleh dan menyimpan informasi yang akan diputuskan oleh pembuat keputusan manajemen dan orang lain untuk membuat produk atau mengirimkan jasa kepada pelanggan. ${ }^{3}$ Pada prinsipnya penerapan teknologi informasi di sebuah perusahaan atau organisasi disesuaikan dengan kebutuhan organisasi, tidak harus selalu memakai teknologi terbaru selama kebutuhan organisasi terhadap teknologi informasi yang telah ada sudah terpenuhi, namun jika dibutuhkan perusahaan harus mempertimbangkan untuk menerapkan teknologi informasi terbaru. Hal tersebut perlu dipertimbangkan karena penerapan teknologi informasi juga berguna untuk menurunkan biaya produksi dan membantu perusahaan menjadi yang kompetitif dalam persaingan dengan perusahaan lain.

Namun dalam menerapkan teknologi informasi didalam sebuah perusahaan harus didukung dengan kemampuan karyawan yang kompeten dalam menggunakan teknologi informasi tersebut. Hal ini dikarenakan yang mengoperasionalkan teknologi informasi sebagian besar adalah

\footnotetext{
' Ariesto Hadi Sutopo, Teknologi informasi dan Komunikasi dalam Pendidikan (Yogyakarta: Graha llmu, 20 I2), I

${ }^{2}$ Ricky W. Griffin, Manajemen Edisi Ketujuh jilid 2 (Jakarta: Erlangga, 2004), 226

${ }^{3}$ Fred Luthans, Perilaku Organisasi Edisi 10 (Yogyakarta: Andi, 2006), 41
} 
sumber daya manusia, dengan demikian perusahaan perlu memperhatikan kemampuan karyawan dalam menggunakan teknologi informasi yang diterapkan. Selain itu kemampuan kerja merupakan salah satu faktor yang sangat penting dan berpengaruh terhadap keberhasilan pegawai dalam melaksanakan pekerjaannya. Kemampuan merupakan suatu hasil kerja yang dilakukan oleh seseorang dalam menyelesaikan pekerjaannya yang diukur berdasarkan kecakapan, pengalaman, dan kesungguhan serta waktu. ${ }^{4}$

Sedangkan untuk pemilihan variabel teknologi informasi alasan peneliti selain karena memang perkembangan teknologi yang sangat pesat juga dikarenakan Kopotren MHI Jember ini baru menerapkan sistem terpadu berbasis teknologi informasi dengan harapan meningkatkan kinerja karyawan sehingga dapat memuaskan pelanggan terhadap pelayanan yang diberikan. Dalam sebuah artikel di website pesantren menyebutkan bahwa "Kopotren telah mengembangkan aplikasi pengajuan kredit online yang bisa digunakan seluruh masyarakat Jombang dan sekitarnya. Dengan aplikasi ini calon nasabah tidak perlu datang ke kantor untuk mendapatkan kredit cukup hanya dengan mengisi data yang telah ditentukan. Layanan yang lainnya yaitu pembukaan deposito, tabungan, simulasi kredit, form pengaduan, chat via Whatsapp, Telegram Channe, jaringan kantor, facebook, dll.". ${ }^{5}$ Selain itu dengan penerapan teknologi informasi diharapkan mampu bersaing dengan Koperasi simpan pinjam lainya termasuk BMT yang lebih unggul. Harapan itulah yang juga menjadi alasan penelti memilih variabel kinerja karyawan dan sudah dibuktikan oleh penelitian-penelitian sebelumnya bahwa ada hubungan yang positif antara penerapan teknologi informasi dengan kinerja karyawan.

\footnotetext{
${ }^{4}$ Malayu Hasibuan SP., Manajemen Sumber Daya Manusia (Jakarta: Bumi Aksara, 2005), 94

5 "Berita, Pengajuan Kredit Bank Jombang Lebih Mudah dengan Aplikasi Pengajuan Kredit Online 2017", dalam https://www.bankjombang.com diakses pada 3 Februari 2018 pukul $19.03 \mathrm{WIB}$
} 
Dalam penelitian ini penulis memilih Kopotren MHI Jember sebagai studi kasus penelitian karena Koperasi ini merupakan Koperasi simpan pinjam milik pesantren, semua modal usaha berasal dari Pesantren dan iuran anggota. Selain itu karena Koperasi ini termasuk lembaga ekonomi yang baru mengalami perkembangan yang baik.". 6 Dengan keadaan yang baru berkembang inilah yang menjadi titik ketertarikan peneliti karena dengan perusahaan yang masih dalam level berkembang akan semakin mudah dinilai produktivitasnya dengan dilihat dari kinerja karyawannya (dimana persamaan kinerja karyawan yang tinggi maka kinerja organisasi juga akan tinggi), apalagi saat ini teknologi informasi juga baru diterapkan di dalam Kopotren MHI Jember tersebut, maka tingkat produktivitas perusahaan dapat diukur melalui perbandingan sebelum penerapan teknologi informasi dengan sesudah penerapan teknologi informasi.

Berdasarkan uraian latar belakang diatas dan dari hasil penelitian terdahulu maka penulis melakukan penelitian dengan mengambil judul "Pengaruh Penerapan Teknologi Informasi Terhadap Kinerja Karyawan Dengan Kemampuan Kerja Sebagai Variabel Moderasi Di Koperasi Pondok Pesantren Mambaul Khoiriyatil Islamiyah (MHI) Jember".

Adapun rumusan masalah dalam penelitian ini: Pertama; Bagaimana pengaruh penerapan teknologi informasi terhadap kinerja karyawan Koperasi Pondok Pesantren Mambaul Khoiriyatil Islamiyah (MHI) Jember?. Kedua; Bagaimana kemampuan pengguna memoderasi pengaruh penerapan teknologi informasi terhadap kinerja karyawan Koperasi Pondok Pesantren Mambaul Khoiriyatil Islamiyah (MHI) Jember?

Tujuan penelitian ini adalah : Pertama; Untuk mengetahui bagaimana pengaruh penerapan teknologi informasi terhadap kinerja karyawan Koperasi Pondok Pesantren Mambaul

\footnotetext{
6 "BPR Bank Jombang Bange Wong Jombang Semakin Berkembang 20 I3", dalam jombangkab.go.id/index.php/web/entry/bpr-bank-jombang-bange-wong-jombang-semakinberkembang-.html diakses pada 3 Februari 2018 pukul 19.15 WIB
} 
Khoiriyatil Islamiyah (MHI) Jember. Kedua; Untuk mengetahui bagaimana kemampuan pengguna memoderasi pengaruh penerapan teknologi informasi terhadap kinerja karyawan Koperasi Pondok Pesantren Mambaul Khoiriyatil Islamiyah (MHI) Jember

Kegunaan Penelitian ini adalah: Pertama; Kegunaan Teoritis, Penelitian ini diharapkan dapat menjadi referensi sebagai sumber informasi untuk menambah wawasan pengetahuan dan dapat bermanfaat untuk peneliti selanjutnya, khususnya yang terkait dengan pengaruh penerapan teknologi informasi terhadap kinerja karyawan dengan dimoderasi oleh kemampuan pengguna. Kedua; Kegunaan Praktis, Penelitian ini dapat dijadikan sebagai bahan referensi dalam membuat kebijakan terutama dalam bidang penerapan teknologi informasi, peningkatan kinerja dan kemampuan karyawan sebagai penunjang dalam meningkatkan perkembangan perusahaan

\section{Landasan Teori}

1. Pengertian Teknologi Informasi

Martin, dkk mendefinisikan teknologi informasi sebagai kombinasi antara teknologi komputer dengan teknologi komunikasi, teknologi komputer yang terdiri dari perangkat keras dan perangkat lunak yang berfungsi untuk mengolah dan menyimpan informasi sedangkan teknologi komunikasi berfungsi untuk melakukan transmisi informasi. Menurut Thomas McKeown mendefinisikan teknologi informasi sebagai seperangkat teknologi yang mempunyai fungsi untuk membuat, menyimpan, mengubah, dan menggunakan informasi dalam bentuk apapun. $^{7}$

Teknologi informasi mengacu kepada sumber daya yang digunakan oleh organisasi untuk mengelola informasi yang diperlukan demi mewujudkan misinya. Istilah yang

7 Muhammad Suyanto, Pengantar Teknologi Informasi (Yogyakarta: Andi, 2005), 10 
berhubungan adalah teknologi informasi (information technology-IT). IT bisa terdiri dari komputer, jaringan komputer, telepon, mesin faks, perangkat-perangkat keras lainnya. Selain itu, IT juga melibatkan perangkat lunak yang memfasilitasi kemampuan sistem untuk mengelola informasi dengan cara yang bermanfaat bagi manajer. ${ }^{8}$

2. Penerapan Teknologi Informasi

Kemajuan teknologi informasi yang sangat pesat ini benar-benar menyebabkan dunia menjadi tempat yang lebih sempit dan tanpa ada batas karena teknologi informasi jangkauannya sangat luas. Sehingga teknologi informasi menjadi kebutuhan utama di dalam sebuah organisasi.

Peranan teknologi yang terdiri dari berbagai jenis teknologi, teknologi yang digunakan di system teknologi informasi adalah teknologi komputer, teknologi komunikasi dan teknologi informasi apapun yang memberikan nilai tambah untuk organisasi dari berbagai jenis teknologi informasi yang mempunyai dampak sangat besar terhadap setiap aspek kehidupan dan paling penting saat ini adalah komputer. ${ }^{9}$

Tujuan penerapan teknologi informasi bagi perusahaan atau organisasi yang bersangkutan adalah untuk mendapatkan rantai nilai dari teknologi informasi yang mempunyai manfaat untuk semua aspek bisnis dengan berorientasi kepada peningkatan kinerja karyawan dan produktivitas perusahaan guna mendapatkan keuntungan yang maksimal tetapi resiko dan biaya seminimal mungkin. ${ }^{10}$

Efektivitas pemanfaatan teknologi informasi akan memberi kontribusi agar tugas-tugas dapat dilaksanakan dengan baik. Hal itu dapat diperoleh dengan memenafaatkan teknologi informasi untuk menurunkan

${ }^{8}$ Ricky W. Griffin, Manajemen Edisi Ketujuh jilid 2 (Jakarta: Erlangga, 2004), 227

9 Jogiyanto,dkk, Sistem Informasi dan Teknologi Informasi (Yogyakarta: Andi, 2009), 19

${ }^{10}$ Ririn Wiseliner, op.cit., 18 
human error, seperti lupa, turunnya presisi karena kelelahan,dan lain-lain. ${ }^{11}$

3. Kemampuan Pengguna

Kemampuan (ability) merupakan salah satu sifat bawaan manusia yang digunakan untuk melaksanakan suatu tindakan atau pekerjaan mental atau fiskal. ${ }^{12}$ Pengertian lain menjelaskan bahwa kemampuan diartikan sebagai ciri luas dan karakteristik tanggung jawab yang stabil pada tingkat prestasi yang maksimal berlawanan dengan kemampuan kerja mental maupun fisik. Pegawai yang memiliki kemampuan memadai akan dapat menyelesaikan pekerjaannya dengan baik sesuai dengan waktu atau target yang telah ditetapkan dalam program kerja. ${ }^{13}$

Kemampuan atau ability menunjukkan kapasitas individu untuk melakukan beragam tugas dalam suatu pekerjaan. Kemampuan yang dimiliki seorang individu pada umumnya tersusun dari dua perangkat faktor, yaitu kemampuan intelektual dan kemampuan fisik. ${ }^{14}$

Kemampuan adalah bakat seseorang untuk melakukan tugas fisik atau mental. Kemampuan seseorang pada umumnya stabil selama beberapa waktu. Kemampuan telah didefinisikan sebagai faktor-faktor yang penting untuk membantu memberdayakan karyawan yang berkinerja tinggi dengan yang berkinerja rendah: kemampuan mental, inteligensiemosi (emotional intelligence), dan tacit knowledge..$^{15}$

Kemampuan (ability) berdampak pada kinerja (job performance) dan komitmen (commitment), namun

\footnotetext{
" Hamzah B.Uno dan Nina Lamatenggo, Teknologi Komunikasi dan Informasi Pembelajaran (Jakarta: Bumi Aksara,20I I), 59

${ }^{12}$ J. Winardi, Manajemen Perilaku Organisasi Edisi Revisi (Jakarta: Prenada Media Grup, 2004), 201

${ }^{13}$ Robert Kreitner dan Kinicki Angelo, Perilaku Organisasi (Jakarta: Salemba Empat, 2003), 185

${ }^{14}$ Stephen P. Robbins dan Timothy A. Judge, Perilaku Organisasi (Jakarta: Prehallindo, 1998), 40

${ }^{15}$ John M. Ivancevich,dkk, Perilaku dan Manajemen Organisasi (Jakarta: Erlangga, 2008), 8586 (alih bahasa gina gania)
} 
tergantung pada jenis kemampuan yang mana, cognitive, emotional, atau physical. Bentuk kemampuan yang paling relevan untuk semua pekerjaan adalah general cognitive ability. General cognitive ability merupakan predikator paling kuat dari job performance, pada khususnya aspek task performance. Disemua pekerjaan, pekerja yang lebih cerda memenuhi semua kebutuhan deskripsi pekerjaan lebih efektif daripada pekerja yang kurang cerdas. Hal tersebut terjadi karena pekerja dengan general cognitive ability lebih tinggi cenderung lebih baik dalam pembelajaran dan pengambilan keputusan. Mereka dapat memanfaatkan lebih banyak pengetahuan dari pengalaman dengan lebih cepat,dan sebagai hasilnya mereka mengembangkan pengetahuan yang lebih besartentang bagaimana melakukan pekerjaan lebih efektif. ${ }^{16}$

Ada atau tidak adanya kemampuan memiliki hubungan yang nyata terhadap kinerja pekerjaan. Manajer harus berusaha menyesuaikan kemampuan seseorang dengan kebutuhan pekerjaan. Proses penyesuaian ini penting karena tidak ada kepemimpinan, motivasi, atau sumber daya organisasi yang dapat mengatasi kekurangan kemampuan. ${ }^{17}$

4. Kinerja Karyawan

Kinerja (performance) adalah hasil pekerjaan yang dicapai seseorang berdasarkan persyaratan-persyaratan pekerjaan (job requirement). ${ }^{18}$ Kinerja (performance) adalah hasil kerja yang bersifat kongkret yang dapat diamati, dilihat dan diukur. ${ }^{19}$ Kinerja karyawan adalah sebuah prestasi kerja atau hasil kerja (output) baik secara kualitas maupun kuantitas yang dicapai oleh seorang karyawan dalam melaksanakan pekerjaanya sesuai dengan tanggungjawab yang dibebankan kepadanya. Kinerja

\footnotetext{
16 lbid., 107

17 John M. Ivancevich,dkk, op.cit., 87

18 Wilson Bangun, Manajemen Sumber Daya Manusia (Jakarta: Erlangga, 20 I 2), 23 I

${ }^{19}$ Irawan Prasetya, Manajemen Sumber Daya Manusia (Jakarta: STIA-LAN Press, 2000), I I
} 
individu bertujuan sebagai alat yang menyelaraskan antara harapan kerja individu dengan tujuan organisasi. Kesesuaian antara upaya pencapaian tujuan individu dengan tujuan organisasi akan mampu mewujudkan kinerja yang baik. ${ }^{20}$

Sedangkan pengertian lain menjelaskan kinerja atau performance merupakan gambaran mengenai tingkat pencapaian pelaksanaan suatu program kegiatan atau kebijakan dalam mewujudkan sasaran, tujuan, visi, dan misi organisasi yang dituangkan melalui perencanaan strategis suatu organisasi. ${ }^{21}$

5. Faktor-Faktor yang dapat Mempengaruhi Kinerja Faktor-faktor yang dapat mempengaruhi kinerja antara lain $: 22$

1) Faktor kemampuan (ability)

Dalam arti psikologis kemampuan karyawan terbagi dalam dua jenis kemampuan yaitu kemampuan potensi (IQ) dan kemampuan reality (knowledge dan skill). Jadi dapat disimpulkan karyawan yang memiliki IQ yang tinggi (diatas rata-rata) dengan didukung latar pendidikan yang tinggi dan sesuai dengan jabatan yang diduduki serta terampil dalam melaksanakan pekerjaannya, maka kinerja karyawan tersebut dapat dengan mudah untuk ditingkatkan.

2) Faktor motivasi (motivation)

Motivasi merupakan suatu kondisi yang memberikan dorongan terhadap diri seseorang untuk melakukan suatu kegiatan. Secara umum motivasi terbentuk dari sikap (attitude) seorang individu dalam menghadapi situasi (situation) atau kondisi tertentu. Dalam melakukan suatu pekerjaan motivasi sangat

\footnotetext{
${ }^{20}$ A. P. Mangkunegara, Evaluasi Kinerja SDM (Bandung: PT Refika Aditama, 2009), 9

21 Moeheriono, Pengukuran Kinerja Berbasis Kompetensi (Bogor: Ghalia Indonesia, 2009), 60 22 A.P. Mangkunegara, Manajemen Sumber Daya Manusia Perusahaan (Bandung: PT Remaja Rosdakarya, 2008), 67-68
} 
dibutuhkan seorang karyawan agar bisa mencapai kinerja yang tinggi.

6. Alat ukur kinerja

Menurut Wilson menyebutkan alat ukur kinerja sebagai berikut :

1) Jumlah pekerjaan, dimensi ini menunjukkan jumlah pekerjaan yang dihasilkan individu atau kelompok sebagai persyaratan yang menjadi standar pekerjaan.

2) Kualitas pekerjaan, setiapkaryawan dalam perusahaan harus memenuhi persyaratan tertentu untuk dapat menghasilkan pekerjaan sesuai kualitas yang dituntut suatu pekerjaan tertentu.

3) Ketepatan waktu, setiap pekerjaan memiliki karakteristik yang berbeda, untuk jenis pekerjaan tertentu harus diselesaikan tepat waktu,karena meiliki ketergantungan atas pekerjaan lainnya

4) Kehadiran, suatu pekerjaa tertentu menuntut kehadiran karyawan dalam mengerjakannya sesuai waktu yang ditentukan

\section{Hipotesa Dan Jenis Penelitian}

1. Hipotesis

1) H1 : Terdapat pengaruh antara penerapan teknologi informasi terhadap kinerja karyawan

2) $\mathrm{H} 2$ : Kemampuan pengguna mempunyai pengaruh terhadap hubungan antara penerapan teknologi informasi dengan kinerja karyawan

2. Kerangka Penelitian 


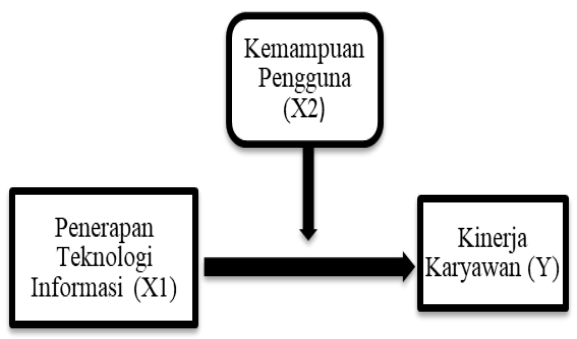

\section{Jenis Penelitian}

Jenis Penelitian ini, dalam penelitian ini menggunakan jenis penelitian kuantitatif, yaitu dimana data penelitan berupa angka-angka dan metode analisisnya menggunakan statistik. ${ }^{23}$

Waktu dan Tempat Penelitian, Penelitian ini dilakukan di Koperasi Pondok Pesantren Mambaul Khoiriyatil Islamiyah (MHI) Jember tepatnya di Komplek Asrama Aruqoyyah Pon Pes Mambaul Khoiriyatil Islamiyah (MHI) Jl. Balung Dsn. Kedungsuko Ds. Bangsalsari Kec. Bangsalasari Kab. Jember dan penelitian ini dilakukan pada bulan Februari sampai dengan Maret 2018. Dalam penelitian ini yang menjadi populasi adalah seluruh karyawan dari segala bidang dan yang menggunakan teknologi informasi dalam menyelesaikan pekerjaannya di Koperasi Pondok Pesantren Mambaul Khoiriyatil Islamiyah (MHI) Jember.

Sampel yang digunakan dalam penelitian ini adalah seluruh karyawan berada di Kopotren sebanyak 60 orang yang memanfaatkan penerapan teknologi informasi dalam menjalankan pekerjaannya.

\section{Variabel Penelitian}

1) Variabel Independen (Bebas)

Variabel Independen (bebas) adalah variabel yang tidak terikat, tidak dipengaruhi, bahkan mempengaruhi atau menjadi penyebab perubahan atau timbulnya variabel

\footnotetext{
${ }^{23}$ Sugiyono, Metode Penelitian Kuantitatif Kualitatif dan R\&D (Bandung,Alfabeta, 20 I 4), 6-7
} 
lain (variabel terikat).24 Dalam penelitian ini yang menjadi varial independen (bebas) adalah penerapan teknologi informasi dengan indikator antara lain faktor sosial, perasaan, kondisi yang memfasilitasi, konsekuensi jangka panjang, kesesuaian tugas. ${ }^{25}$

2) Variabel Dependen (Terikat)

Variabel dependen (terikat) adalah variabel yang dipengaruhi atau variabel akibat adanya variabel independen (bebas). ${ }^{26}$ Dalam penelitian ini yang menjadi variabel dependen (terikat) adalah kinerja karyawan dengan indikator kualitas, kuantitas, efektivitas, ketepatan waktu. ${ }^{27}$

3) Variabel Moderating Variabel moderating adalah salah satu variabel yang berperan untuk memperkuat atau memperlemah pengaruh hubungan antara variabel independen (bebas) dengan variabel dependen (terikat). ${ }^{28}$ Dalam penelitian ini yang menjadi variabel moderating adalah kemampuan pengguna dengan indikator pengetahuan, kemampuan, keahlian. ${ }^{29}$

5. Metode Pengumpulan Data

Ada dua jenis data pada penelitian ini yaitu data primer dan data sekunder. Untuk data primer didapatkan melalui kuisioner, observasi dan wawancara kepada responden. Sedangkan data sekunder didapatkan melalui sumber-sumber studi pustaka yang relevan dengan topik penelitian baik dari buku-buku maupun penelitian terdahulu.

\section{Analisa Data}

1. Metode Analisis Data

\footnotetext{
${ }^{24}$ Irfan Tamwifi, Metode Penelitian (Surabaya: UIN Sunan Ampel Press, 20I 4), 199

${ }^{25}$ Sabihaini, Analisis Pemanfaatan Teknologi Informasi dan Kinerja Individual (Surabaya:

Universitas Katolik Widya Mandala, 2006), 5

${ }^{26}$ Ibid., 200

27 Stephen P Robbin, Perilaku Organisasi (Jakarta: Salemba Empat, 2006), 260

${ }^{28}$ Irfan Tamwifi, loc. cit.

${ }^{29}$ Stephen P Robbin dan Judge, op. cit., 45
} 
1) Uji Kualitas Data

a) Uji Validitas

Dalam penelitian ini menggunakan metode korelasi produk moment (moment product correlation). Nilai korelasi yang diperoleh dari (mengkorelasikan antara skor masing-masing item pernyataan dengan skor total item pertanyaan tersebut lalu dibandingkan dengan nilai korelasi (r), jika R $\mathrm{R}_{\text {hitung }}$ lebih besar dari Rtabel berarti pertanyaan dianggap memenuhi kriteria validitas.

Dalam penelitian ini jumlah sampel yang digunakan untuk uji validitas sebanyak 40 responden, maka nilai $R_{\text {tabel }}$ dihitung dari analisis $d f$ (degree of freedom) dengan rumus $\mathrm{df}=\mathrm{n}-\mathrm{k}, \mathrm{n}$ adalah jumlah responden dan $\mathrm{k}$ adalah jumlah variabel dependen, jadi $\mathrm{df}=40-2=38$ berdasarkan tabel $r$ product moment diperoleh nilai Rtabel sebesar 0.312, dan hasilnya menunjukkan semuaitem pertayaan valid.

b) Uji Realibilitas

Dalam penelitian ini menggunakan metode Cronbach Alpha $(\propto)$. Kuisioner dinyatakan reliabel jika mempunyai nilai $(\propto)>0,60$, dari hasil penelitian menunjukkan indikator variabel dikatakan reliabel.

2) Uji Asumsi Klasik

Ada beberapa cara untuk uji asumsi klasik, antara lain ${ }^{30}$

a) Uji Normalitas

Pada penelitian ini alat uji statistik menggunakan Kolmogrov Smirnov dengan melihat nilai signifikasi variabel, jika signifikan lebih besar $\alpha=$ 5\% maka menunjukkan distribusi data normal. Berdasarkan hasil uji normalitas untuk seluruh variabel nilai Asymp Sig. (2-tailed) sebesar 0.805. Hal

30 Singgih Santoso, Statistik Multivariat (Jakarta: PT Elex Media Komputindo, 20 I 4), 43 
ini membuktikan bahwa data dalam penelitian ini berdistribusi normal karena nilai $0.805>0.05$.

b) Uji Heteroskedastisitas

Berdasarkan hasil uji menujukkan nilai signifikansi masing-masing varibel $>0.05$, maka sesuai metode uji Glejser yang digunakan dalam penelitian hasilnya dapat dikatakan variabel independen yaitu variabel penerapan teknologi informasi bernilai 0,378 dan variabel kemampuan pengguna bernilai 0,418 jadi dikatakan bebas dari gejala heteroskedasitas.

c) Uji Multikolinieritas

Pada penelitian ini menggunakan alat statistik Variances Inflation Factor (VIF). Jika nilai tolerance lebih besar dari 0,1 dan nilai VIF lebih kecil dari 10 serta nilai matriks korelasi tidak ada yang lebih besar dari 0,5, maka tidak terjadi multikolinieritas. Berdasarkan tabel diatas menunjukkan nilai tolerance masing-masing variabel $>0.10$ yaitu $(0,909)$ dan nilai VIF masing-masing variabel < 10.00 yaitu (1100), maka dapat dikatakan tidak terjadi multikolonieritas dalam data penelitian tersebut.

d) Uji Autokorelasi

Dalam penelitian ini uji autokorelasi dilakukan dengan metode Uji Run dengan melihat nilai Asymp Sig (2-tailed) harus lebih besar 0,05. Berdasarkan hasil uji autokorelasi menunjukkan Asymp Sig.(2tailed) bernilai 0,118 yang artinya nilainya lebih besar dari 0,05 sehingga dapat disimpulkan model bebas dari gejala autokorelasi.

2. Uji Hipotesis

1) Untuk hipotesis pertama digunakan alat uji dengan metode regresi linier sederhana untuk menentukan 
ketetapan prediksi dari pengaruh yang terjadi antara variabel independen terhadap variabel dependen.

Data hasil uji menunjukkan bahwa nilai $R$ sebesar 0,270 yang artinya hubungan antara penerapan teknologi informasi terhadap kinerja karyawan sebesar $27 \%$. Sedangkan untuk adjusted $R$ square menunjukkan nilai sebesar 0.057 yang artinya hanya $5,7 \%$ variabel penerapan teknologi informasi mampu menjelaskan variabel kinerja karyawan sisanya sebesar $(100 \%-5,7 \%)$ $=94,3 \%$ dijelaskan olehvariabel lainnya yang tidak dimasukkan dalam pengujian ini.

Selain itu dari uji terlhat nilai $\mathrm{F}$ menunjukkan angka 4,578 dengan signifikansi sebesar 0,037 sehingga dapat disimpulkan bahwa penerapan teknologi informasi berpengaruh terhadap kinerja karyawan karena nilai signifikansi $<$ (kurang dari) 0,05.

$$
\mathrm{Y}=15,176+0,292 \mathrm{X}_{1}+\mathrm{e}
$$

Dari persamaan tersebut menunjukkan nilai koefisien penerapan teknologi informasi yaitu sebesar 0,292 yang bernilai positif artinya bahwa variabel penerapan teknologi informasi mempunyai pengaruh positif dan signifikan terhadap kinerja karyawan, dengan nilai konstanta diketahui dalam tabel sebesar 15,176 yang diartikan sebagai nilai kinerja karyawan secara konstan.

2) $\mathrm{H} 2 \quad$ Kemampuan pengguna mempunyai pengaruh terhadap hubungan antara penerapan teknologi informasi dengan kinerja karyawan

Uji interaksi dilakukan dengan menggunakan Moderated regression analysis (MRA) yaitu aplikasi dari regresi linier berganda dimana dalam persamaanya mengandung unsur interaksi (perkalian dua/lebih variabel independen). MRA dilakukan melalui uji signifikansi simultan (Uji F) dan Uji signifikansi parameter individual 
(Uji t) dengan ketentuan sebagai berikut: Uji signifikansi simultan (uji ststistik F). Jika anova atau F test menghasilkan nilai $\mathrm{F}$ hitung dengan tingkat signifikansi yang lebih kecil dari tingkat signifikansi yang ditentukan, maka model regresi dapat digunakan untuk memprediksi variabel Y. uji signifikansi parameter individual (Uji $t$ statistik), jika variabel independen, moderating dan interaksi memberikan nilai koefisien parameter dengan tingkat signifikansi lebih kecil dari tingkat signifikansi yang ditentukan, maka dapat disimpulkan bahwa variabel tersebut adalah variabel moderasi. ${ }^{31}$

Berdasarkan hasil uji dapat diketahui nilai $R$ sebesar 0,298 yang artinya hubungan antara penerapan teknologi informasi terhadap kinerja karyawan yang dimoderasi oleh kemampuan pengguna sebesar 29,8\%. Sedangkan nilai Adjusted $R$ Square menunjukkan angka sebesar 0,040 yang berarti variabel kinerja karyawan dapat dijelaskan oleh variabel penerapan teknologi informasi yang dimoderasi oleh variabel kemampuan pengguna hanya sebesar $4 \%$ sisanya sebesar $(100 \%-4 \%)$ $=96 \%$ dijelaskan oleh variabel-variabel lain yang tidak di uji dalam model penelitian ini.

Dari hasil uji menunjukkan nilai Fhitung sebesar 1,816 dengan nilai signifikansi sebesar 0,155 yang artinya nilai signifikansi lebih besar dari 0,05, maka dapat dikatakan bahwa secara bersama-sama variabel-variabel independen (penerapan teknologi informasi dan kemampuan pengguna) beserta variabel moderasi tidak berpengaruh secara signifikan terhadap variabel dependen yaitu kinerja karyawan.

$$
\mathrm{Y}=30,533-0,579-0,683+0,039 \mathrm{X} 1 \mathrm{X} 2+\mathrm{e}
$$

\footnotetext{
${ }^{31}$ Imam Ghozali, Aplikasi Analisis Multivarite Dengan Program SPSS (Yogyakarta: Universitas Diponegoro, 2006), 60
} 
Dari persamaan tersebut dapat ditunjukkan bahwa konstanta bernilai 30,533, sedangkan nilai koefisien masing-masing variabel berbeda-beda variabel penerapan teknologi informasi bernilai negative sebesar $(-0,579)$, kemampuan pengguna bernilai negatife sebesar $(-0,683)$, dan untuk variabel moderasi (interaksi antara penerapan teknologi informasi dan kemampuan pengguna) menunjukkan nilai positif sebesar 0,039. Selain itu nilai signifikansi tabel menunjukkan angka lebih besar dari 0,05 sehingga menjadi disimpulkan bahwa semua variabel bernilai tidak signifikan. Dengan kata lain variabel moderasi pada hasil uji penelitian ini disebut sebagai variabel moderasi potensial (homologiser) dimana nilai b2 dan b3 bernilai negative yaitu variabel yang potensial menjadi variabel moderasi yang mempengaruhi kekuatan hubungan antara variabel independen dan variabel dependen, variabel ini tidak berinteraksi dengan variabel independen dan tidak mempunyai hubungan yang signifikan terhadap variabel dependen.

\section{Penutup}

Hasil penelitian ini hipotesis pertama diterima, yaitu penerapan teknologi informasi mempunyai pengaruh positif yang signifikan terhadap kinerja karyawan, dengan kata lain variabel $\mathrm{X} 1$ berpengaruh terhadap variabel $\mathrm{Y}$.

Penelitian ini menghasilkan hipotesis kedua diterima tetapi hasilnya menunjukkan koefisien variabel moderasi bernilai positif yang artinya variabel moderasi berpengaruh tidak signifikan dan bersifat memperlemah hubungan interaksi antara penerapan teknologi informasi dan kinerja karyawan. Sehingga disimpulkan bahwa kemampuan pengguna sebagai variabel moderasi potensial. Selain itu penelitian ini menunjukkan dari hasil uji regresi kedua secara bersama-sama (simultan) variabel-variabel independen beserta variabel moderasi tidak berpengaruh terhadap kinerja karyawan, jadi 
Akh. Yunan Atho'illah

variabel kemampuan pengguna yang menjadi variabel moderasi tetapi tidak signifikan juga tidak dapat menjadi variabel dependen karena hasil uji menunjukkan nilai yang tidak signifikan. 


\section{DAFTAR PUSTAKA}

Bangun, Wilson. Manajemen Sumber Daya Manusia. Jakarta: Erlangga. 2012.

Ghozali, Imam. Aplikasi Analisis Multivarite Dengan Program SPSS. Yogyakarta: Universitas Diponegoro. 2006.

Griffin, Ricky W., Manajemen Edisi Ketujuh Jilid 2, Erlangga, Jakarta, 2004, hlm 226

Hadi, Ariesto Sutopo. Teknologi informasi dan Komunikasi dalam Pendidikan. Yogyakarta: Graha Ilmu. 2012.

Hasibuan, Malayu. Manajemen Sumber Daya Manusia. Jakarta: Bumi Aksara. 2005.

Jogiyanto,dkk. Sistem Informasi dan Teknologi Informasi. Yogyakarta: Andi. 2009.

Kreitner, Robert dan Kinicki Angelo. Perilaku Organisasi. Jakarta: Salemba Empat. 2003.

Luthans, Fred. Perilaku Organisasi Edisi 10. Yogyakarta: Andi. 2006.

Mangkunegara, A.P. Manajemen Sumber Daya Manusia Perusahaan. Bandung: PT Remaja Rosdakarya. 2008.

M. Ivancevich, John, dkk, Perilaku dan Manajemen Organisasi. Jakarta: Erlangga. 2008

Moeheriono. Pengukuran Kinerja Berbasis Kompetensi. Bogor: Ghalia Indonesia. 2009.

Prasetya, Irawan. Manajemen Sumber Daya Manusia. Jakarta: STIA-LAN Press. 2000.

Robbins, Stephen P. dan Timothy A. Judge. Perilaku Organisasi. Jakarta: Prehallindo. 1998. 
Robbins, Stephen P. Perilaku Organisasi. Jakarta: Salemba Empat. 2006.

Sabihaini. Analisis Pemanfaatan Teknologi Informasi dan Kinerja Individual. Surabaya: Universitas Katolik Widya

Mandala. 2006.

Santoso, Singgih. Statistik Multivariat. Jakarta: PT Elex Media Komputindo. 2014.

Sugiyono. Metode Penelitian Kuantitatif Kualitatif dan RED. Bandung: Alfabeta. 2014..

Suyanto, Muhammad. Pengantar Teknologi Informasi. Yogyakarta: Andi. 2005.

Tamwifi, Irfan. Metode Penelitian. Surabaya: UIN Sunan Ampel Press. 2014.

Uno, Hamzah dan Nina Lamatenggo. Teknologi Komunikasi dan Informasi Pembelajaran. Jakarta: PT Bumi Aksara .2011 .

Winardi, J. Manajemen Perilaku Organisasi Edisi Revisi. Jakarta: Prenada Media Grup. 2004.

Wiseliner, Ririn. "Pengaruh Penerapan Teknologi Informasi Terhadap Kinerja Karyawan Pada PT. Serasi AutorayaTrac Astra Rent Car Cabang Pekanbaru". Skripsi Sarjana-UIN SUSKA Riau. 2013.

https://www.bankjombang.com diakses pada 3 Februari 2018 pukul 19.03 WIB

jombangkab.go.id/index.php/web/entry/bpr-bank-jombangbange-wong-jombang-semakin-berkembang-html diakses pada 3 Februari 2018 pukul 19.15 WIB 